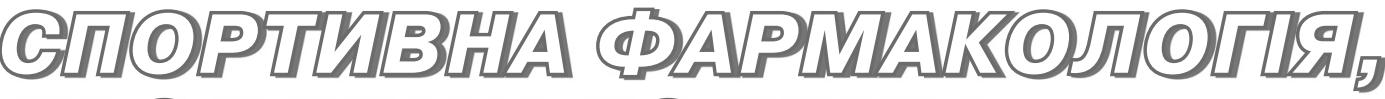

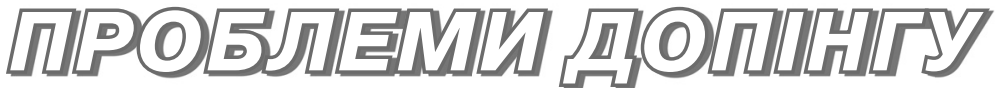

\section{Сучасні лабораторні критерії в системі медико-біологічного контролю спортсмена: необхідний та достатній перелік}

\author{
Л. М. Гуніна, Д. Л. Ткачова \\ НДІ Національного університету фізичного виховання і спорту України, \\ Київ, Україна
}

\begin{abstract}
Резюме. Приведен перечень современных лабораторных показателей, которые могут быть использованы при научно-методическом обеспечении подготовки спортсменов для оценки их функционального состояния и состояния основных систем обеспечения жизнедеятельности организма. Рассмотрены новые данные в аспекте лабораторной диагностики начальных проявлений перетренированности и субклинических признаков спортивно-медицинской патологии. Освещены основные проблемы службы лабораторной диагностики в украинском спорте, не дающие тренеру возможности получать качественную достоверную информацию относительно состояния здоровья, подготовленности и адаптационных возможностей спортсмена.
\end{abstract}

Ключевые слова: лабораторная диагностика, спортивная подготовка, тренированность, заболевания спортсменов.

\begin{abstract}
Summary. A list over of modern laboratory indexes is brought in the analytical article what can be used during the scientifically-methodical providing of preparation of sportsmen for the estimation of their functional state and state of the basic systems of providing of vital functions of organism. New data are considered in the aspect of the laboratory diagnostic of initial displays of overtraining and subclinical signs of sporting-medical pathology. The basic problems of service of laboratory diagnostics are lighted up in Ukrainian sport, which do not give an opportunity to the trainer to get high-quality reliable information on the state of health, preparedness and adaptation possibilities of sportsman.
\end{abstract}

Key words: laboratory diagnostics, sporting preparation, overtraining, sportsmen disease.

Постановка проблеми. Відомо, що спорт вищих досягнень неможливий без підтримки якісного стандартизованого медико-біологічного забезпечення, на перші позиції якого виходять функціональні і лабораторні діагностичні процедури [3]. Лабораторний контроль покликаний своєчасно виявляти зрушення в організмі вже на молекулярному та клітинному рівні, що проявляються внаслідок надмірних фрізичних навантажень, яких зазнає профресійний спортсмен, а також впливу несприятливих умов зовнішнього середовища, зміни часових поясів, незбалансованого харчового раціону, спадкової схильності до розвитку певних захворювань, при виникненні спортивно-медичної патології, передусім з боку серцево-судинної і гепатобіліарної систем, опорно-рухового апарату тощо $[1,8] .3$ метою оцінки фуннціонального стану основних лімітуючих систем, а також життєво важливих органів, для визначення резервів та адаптаційного потенціалу спортсменів використовується великий перелік гематологічних, біохімічних, імунологічних, ендокринологічних та інших параметрів. Сьогодні у світовій практиці для оцінки функціонального стану спортсменів застосовуються навіть технології імуноблотингу, які дають можливість оцінити стан енергопродукування саме в мітохондріях через визначення активності коактиватора 
гамма-рецепторів проліфератора пероксисом (PGC-1 $\alpha$ ) [19].

Для тренерів, спортивних лікарів та й самих спортсменів результати лабораторної діагностики мають бути не лише однією 3 основ для контролю і побудови тренувального процесу, а й слугувати маркерами попередження розвитку перенапруження i перетренованості, виявлення ранніх симптомів перевтоми та пошкодження м'язової тканини, зниження кількості травм, визначення готовності до змагального періоду, моніторингу функцій ендокринної та імунної систем тощо, зокрема при змінах кліматочасових поясів [3, 10, 11, 15].

На жаль, в Україні служба якісної клінічної лабораторної діагностики розвинена недостатньо, а в сорері спортивної медицини - взагалі знаходиться на самому початку свого становлення. Лише окремі лабораторії, що займаються такою діагностикою в спорті, оснащені сучасними автоматичними приладами (ДНДІФКіС, НДІ НУФВСУ, де проводиться внутрішньолабораторний контроль якості досліджень), та жодна (!) спортивна діагностична лабораторія не має акредитації і не бере участі в міжлабораторному контролі якості. Це призводить до того, що провідні збірні команди держави (зокрема, збірна команда України з біатлону) нерідко проходять лабораторні обстеження в неспеціалізованих для галузі спорту, проте добре обладнаних медичних закладах, і тому не отримують обгрунтованого, адаптованого до того або іншого періоду підготовки спортсменів та спрямованості тренувальних навантажень висновку за результатами дослідження. Наступним етапом аналізу результатів отриманих лабораторних показників $€$ їхнє трактування, проте лікарі команд не мають відповідної підготовки для аналізу сучасних біохімічних, гематологічних, імунологічних даних. Таким чином, результати лабораторного контролю, отримані не у спеціальних спортивних лабораторіях, не надають тренеру всебічної інорормації щодо функціонального стану спортсмена.

Однією з основних проблем у сорері спортивної лабораторної діагностики в Україні $€$ відсутність стандартів і переліків необхідних та достатніх біохімічних, гематологічних, імунологічних й інших показників для визначення фрункціонального стану організму спортсмена у різні періоди річного циклу підготовки з метою досягнення кращих спортивних результатів, подовження спортивного довголіття і попередження розвитку хронічних захворювань [3, 5, 8].

Зовсім по іншому лабораторний контроль організований у провідних спортивних країнах світу. Наприклад, у США існує Лабораторна консультативна рада (Laboratory Sport Advisory Council), яка збирає від національних федерацій та аналізує інформацію за даними лабораторного контролю окремих спортсменів і дає рекомендації для формування переліку необхідних лабораторних досліджень. Діяльність спортивно-медичних лабораторій за стандартами ISO-IEC 17025 контролюється американською асоціацією лабораторних акредитацій (The American Association for Laboratory Accreditation). У Німеччині під час медико-біологічного контролю використовують уніфріковані програми, що розроблені Центральним управлінням спортивного обладнання (FES) у Берліні і Дослідницьким інститутом фрізичної культури і спорту в Лейпцизі (ECS) для різних видів спорту та різних кваліфрікаційних категорій. У Росії ці функції покладено на Національне медико-біологічне агентство спорту.

Відповідно до прийнятих у світі вимог, у діагностичних лабораторіях, де проводять медико-біологічний контроль спортсменів, бажано дотримуватися ряду стандартів із забезпечення якості медичних лабораторій, розроблених Міжнародною організацією зі стандартизації, у тому числі ISO 15189 “Міжнародні лабораторії - основні вимоги до якості i компетентності"; ISO 22870 "Проведення біологічних досліджень пацієнта під контролем медичних установ"; ISO 22367 "Медичні лабораторії - зниження кількості помилок шляхом менеджменту ризиків і постійного поліпшення" тощо.

На жаль, українські лабораторії, що беруть участь у медико-біологічному контролі стану спортсменів, не тільки не мають змоги дотримуватися стандартів, а й не володіють навіть необхідним мінімальним переліком аналітичної апаратури, необхідної для здійснення досліджень на світовому рівні, що зазначено у Наказі Міністерства охорони здоров'я України № 696 від 18.08.2010 “Про затвердження Концепції управління якістю клінічних лабораторних досліджень на період до 2015 року".

До того ж, сьогодні в Україні досі застосовуються недостатньо інфрормативні схеми досліджень, які включають проведення загального аналізу крові і сечі (у рідких випадках із застосуванням сучасних автоматизованих приладів), визначення біохімічних показників крові, таких, як загальний білок, білірубін, глюкоза, сечовина, креатинін, сечова кислота, електроліти, лактат, рідко - $\alpha$-амілаза, аланінамінотрансорераза (АЛТ), аспартатамінотрансфераза (АСТ), гамма-глутамілтрансфераза (ГГТ), лужна фросфратаза (ЛФ), лактатдегідрогеназа (ЛДГ), холестерол (ХC), триацилгліцероли (ТГ) [2, 10, 12]. Звичай- 
но, важливість цих показників не підлягає сумніву, проте прогрес не стоїть на місці, і сучасна лабораторна діагностика має у своєму розпорядженні декілька сотень нових різноманітних параметрів, які $\epsilon$ часом більш доцільні, чутливі і специфрічні, ніж наведені вище. 3 іншого боку, величезна кількість лабораторних показників, які можуть бути використані під час медико-біологічного контролю, також має свої недоліки спортивному лікарю стає складно орієнтуватися у великій кількості аналізів, особливо тому, що багато 3 них можуть частково дублювати один одного. I це ще одна причина того, що необхідно складати добре обмірковані, виважені переліки досліджуваних параметрів, які слід визначати у різні періоди (етапи) макроциклу підготовки та у різних ситуаціях. Вважаємо, що слід сорормувати переліки необхідних діагностичних показників при поточних, етапних контрольних, поглиблених обстеженнях та обстеженнях під час змагального періоду. Деякі інші держави колишнього СРСР, передусім Росія [12], не говорячи про провідні спортивні держави світу [16, 18], вже це зробили.

Мета дослідження - сорормувати необхідні та достатні переліки сучасних лабораторних показників, що мають максимальну інформативність щодо функціонального стану основних органів та систем організму спортсмена на різних етапах підготовки.

Результати дослідження та їх обговорення. Для отримання достовірних порівнюваних результатів, які добре відтворюються, слід зупинитися на важливому етапі у сорері лабораторної діагностики, а саме, - правилах підготовки до здачі аналізу біологічної рідини (кров, сеча), оскільки без правильного проведення преаналітичного (тобто до вимірювання) етапу неможлива коректна інтерпретація результатів досліджень, i відповідно, жодна сучасна програма досліджень не буде мати цінності при неправильній підготовці для іï̈ реалізації [14]. Отже, основні правила проведення лабораторних досліджень у спорті для підвищення їхньої інфрормативності такі:

- узяття всіх біологічних матеріалів (кров, сеча тощо) здійснюють до проведення діагностичних процедур і навантажувальних проб;

- кров на біохімічні й гематологічні дослідження беруть строго натщесерце після споживання 200-250 мл несолодкої негазованої рідини;

- кров на гормони беруть тільки до 10-ї години ранку у зв'язку із добовими біоритмами;

- під час забору крові з вени слід виключити емоційне збудження і фрізичне навантаження (навіть підйом сходами!) напередодні та у день до- слідження; безпосередньо перед забором крові необхідно відпочити 10-15 хв;

- виключити споживання жирного, смаженого, гострого, алкоголю; виключити тютюнопаління напередодні та у день дослідження.

Повертаючись до програм лабораторних досліджень, зазначимо, що при складанні необхідного та достатнього переліку показників, у спортивній сорері в першу чергу треба керуватися завданнями лабораторного контролю залежно від етапу підготовки $[2,3,6]$. Поточні обстеження (ПО) проводяться згідно з планом підготовки; етапні комплексні обстеження (ЕКО) $-3-4$ рази на рік; поглиблені медичні обстеження (ПМО) 2 рази на рік. Обстеження змагальної діяльності (ОЗД) проводяться під час виступів спортсменів на головних стартах сезону та інших, за необхідності. У ході ПО визначається поточний функціональний стан спортсмена і рівень тренувального ефректу, проводиться корекція спрямованості й обсягу м'язової роботи, що виконується протягом тренувального процесу $[7,9]$.

У процесі ЕКО і ПМО за допомогою лабораторних маркерів оцінюють сумарний (кумулятивний) тренувальний ефеект. У ході ПМО додатково виявляють передпатологічні й патологічні стани. На заключному етапі підготовки до головних стартів сезону лабораторний контроль активно сприяє відбору і комплектуванню команд із найбільш підготовлених спортсменів, дозволяє дозувати навантаження згідно 3 результатами, отриманими при обстеженнях. Відомо, що глибина біохімічних змін, що виникають у м'язовій тканині, внутрішніх органах, біологічних рідинах організму, залежить при фрізичному навантаженні від його потужності та тривалості. Чим вища інтенсивність роботи та її тривалість, тим більш значні метаболічні зсуви відбуваються в організмі. При перетренованості пряма залежність між цими показниками часто спотворюється; спостерігається виснаження регуляторних систем. Досягнувши певного рівня, накопичені метаболічні зсуви стають одним із факторів, що підсилюють прояви перетренованості та дезадаптації [9]. Лабораторний контроль також дозволяє оцінювати часову, кліматичну і високогірну адаптацію організму спортсмена до нових умов. І, як наслідок, завдяки результатам усіх видів контролю можна проводити своєчасну корекцію метаболічних зрушень, що стає основою для адекватного сприйняття спортсменами тренувальних та змагальних навантажень. Слід зазначити, що за виникнення спортивно-медичної патології лабораторні показники у змозі виявити доклінічні прояви чотирьох основних видів хронічного перенапруження 
(синдрому перенапруження серцево-судинної системи, центральної нервової системи, нервовом'язового апарату або м'язово-больового синдрому, печінково-больового синдрому). На початку тренувального сезону, особливо на загальнопідготовчому етапі підготовчого періоду, у зв'язку з недостатньою тренованістю спортсменів виникають передумови для розвитку гострого фрізичного перенапруження. Хронічне фрізичне перенапруження частіше спостерігається на спеціально-підготовчому етапі тренування, коли рівень тренованості спортсменів досить високий. Таке перенапруження розвивається внаслідок тривалого фрізичного і емоційного навантаження при недостатній адекватності процесів відновлення. Воно може мати місце при фрорсованому тренуванні й тренуванні 3 підвищеними навантаженнями, якщо спортсмени застосовують їх без достатньої попередньої підготовки. Тому своєчасне виявлення лабораторних ознак перенапруження, його тренувальна (на I етапі) і фрармакологічна корекція (на II-III стадії перенапруження) є профрілактикою зриву адаптації [1].

Розглянемо програми лабораторних досліджень у порядку від поглибленого медичного контролю, оскільки він включає найбільшу кількість показників, відносно застосування яких у практиці ми дамо деякі коментарі, до поточного контролю, в якому обмежимося тільки переліком необхідних показників.

I. Поглиблене медичне обстеження проводять 3 метою отримання найбільш повної і всебічної інформації про здоров'я та функціональний стан організму спортсмена. До нього входить обов'язкова лабораторна програма.

1. Загальний аналіз крові з підрахунком ретикулоцитів та визначенням еритроцитарних характеристик (об'єм еритроцита, середній абсолютний та відносний вміст гемоглобіну в еритроциті, анізоцитоз) для оцінки ступеня активності еритропоезу та диференційної діагностики анемій.

2. Загальний аналіз сечі для оцінки функціонування сечовидільної системи під час фрізичних навантажень та оцінки їх адекватності адаптаційному потенціалу спортсмена.

3. Показники гемостазу - фрібриноген, протромбіновий індекс (ПТІ), тромбіновий час, антитромбін-III (АТ-III), активований частковий тромбіновий час (АЧТЧ), розчинні комплекси фрібрин-мономера, Д-димер, фрібриноліз та коефріцієнт мікроциркуляції (за ступенем зміни параметрів гемостазіограми можна вирахувати коефіцієнт порушення мікроциркуляції і втоми у спортсмена після фрізичного навантаження). У практиці лабораторного контролю в спорті по- казники коагулограми, які дають змогу визначити параметри зсідальної і фрібринолітичної систем крові, та її реологічні властивості, що $€$ опосередкованим відображенням швидкості кровообігу, на жаль, у нашій державі практично не застосовуються.

4. Діагностика ризику розвитку кардіологічної дисфрункції і раптової коронарної смерті - мозковий натрійуретичний пептид (BNP), тропонін-І. BNP - важливий кардіомаркер для оцінки тяжкості і стадії серцевої недостатності $\epsilon$ золотим стандартом у діагностичній практиці як у загальній, так й в спортивній кардіології. Тропонін-І $\epsilon$ кардіомаркером першого вибору при діагностиці інораркту міокарда або глибоких ішемічних порушень стану міокарда під час перевантаження [18].

5. Показники вуглеводного обміну (глюкоза, інсулін). Треба зазначити, що інсулін може бути замінений на С-пептид, оскільки останній визначає рівень ендогенного інсуліну, має більший час напіврозпаду у сироватці крові і відповідно потребує менш жорстких умов для взяття крові та iï зберігання [12].

6. Ліпідний обмін - загальний холестерол (ХC), ліпопротеїди низької (ЛПНЩ) та високої щільності (ЛПВЩ), триацилгліцероли (ТГ), підрахунок коефіцієнта атерогенності (відношення вмісту загального холестеролу до вмісту ЛПВП на практиці часто замінюється відношенням XC/ ТГ). Для оцінки ризику важливий не сумарний рівень загального холестеролу, а співвідношення саме його фрракцій ЛПНЩ і ЛПВЩ.

7. Білковий обмін - загальний білок, альбумін, глобулін, білкові фрракції, молекули середньої маси (МСМ) - продукти розпаду структурних білків, сечовина, сечова кислота, креатинін, креатиноросорокіназа (КФК), у тому числі МВ-фрракція, міоглобін. Акцентуємо увагу на таких важливих показниках пошкодження м'язів, як міоглобін та МВ-КФК (специфічна для серцевого м'яза).

8. Функція печінки, жовчовивідних шляхів і підшлункової залози - білірубін, АСТ і АЛТ з розрахунком коефіцієнта де Ритіса, ГГТ, ЛФ, $\alpha$-амілаза, ЛДГ.

9. Еритропоез (сироваткове залізо, фреритин, еритропоетин).

10. Мінеральний обмін і мікроелементи паратиреоїдний гормон, кальцитонін, остеокальцин, магній, кальцій іонізований, фоссрор, калій, натрій, хром, цинк, селен, мідь.

11. Гормональний профріль - тиреотропний гормон (ТТГ), трийодтиронін ( $\left.\mathrm{T}_{3}\right)$ і тироксин $\left(\mathrm{T}_{4}\right)$, загальний тестостерон, глобулін, що зв'язує статеві гормони (ГЗСГ), естрадіол, пролактин, кор- 
тизол, соматотропний гормон (СТГ), інсуліноподібний фактор росту 1 (ІФР-1), катехоламіни (адреналін, норадреналін, дофрамін). Зауважимо, що більш доцільним $\epsilon$ визначення вільних (незв'язаних із білками-переносниками) форм $\mathrm{T}_{3}$, $\mathrm{T}_{4}$ і тестостерону, оскільки концентрація загальних фракцій цих гормонів буде виразно залежати від здатності печінки синтезувати білки-переносники.

12. Імунологічний профріль, що включає визначення гуморальних фракторів, - імуноглобуліни A, G, М, циркулюючі імунні комплекси (ЦІК) - та клітинних фракторів, таких, як Т-лімфоцити, В-лімфоцити, натуральні кілери (NK), Т-хелпери, Т-супресори з підрахунком індексу Т-хелпери/Т-супресори). Визначення імунного статусу спортсменів набуває особливого значення у світлі того, що за інтенсивних фрізичних навантажень у спортсменів реєструють транзиторні імунодефіцити. Вторинний імунодефріцит, що виникає після інтенсивних і виснажливих фрізичних навантажень, характеризується такими ознаками:

- значним пригніченням фагоцитарної активності клітин перифреричної крові, макрофрагів селезінки і печінки;

- зниженням кількості Т-лімфоцитів у перифреричній крові, гальмуванням їхньої реакції на мітогенні стимули, істотним збільшенням кількості і активності Т-супресорів, зниженням співвідношення Т-хелпери/Т-супресори, порушенням експресії рецепторів для інтерлейкіну-І;

- незначним зменшенням кількості і проліферативної активності В-лімфоцитів, різноспрямованими змінами концентрації, синтезу і деструкції імуноглобулінів різних класів. Свідченням виснаження адаптаційних і резервних можливостей імунної системи при інтенсивних орізичних навантаженнях $€$ повне зникнення імуноглобулінів або окремих їх класів у крові. Спортивному імунодефріциту притаманні порушення синтезу і виділення імуноцитами інтерферонів та інтерлейкінів, що часто $€$ найбільш ранньою реакцією на інтенсивне фрізичне навантаження, особливо у поєднанні з психоемоційним стресом. При різкій активації системи “гіпоталамус-гіпофіз-надниркова залоза" мають місце вторинний імунодесріцит або імуносупресія в результаті дії кортикостероїдних гормонів та інших негативних чинників, супутніх фрізичному навантаженню (хронічний оксидативний стрес), що вимагає регуляції механізмів імунного захисту організму спортсмена. Тому важливо вчасно запроваджувати недопінгову фармакологічну підтримку спортсменів за допомогою засобів вітамінно-мінераль- ної спрямованості, імуномодуляторів переважно рослинного походження. Окрім того, внаслідок періодів послабленого імунного захисту організму, спортсмени $\epsilon$ групою високого ризику на захворювання верхніх дихальних шляхів, що звичайно позначається на спортивних результатах $\mathrm{i}$ працездатності [1].

13. Інфекційні захворювання (гепатити В і С, ВІЛ). Спорт вищих досягнень здебільшого $€$ високотравматичним, і ризик потрапляння різноманітних біологічних рідин (кров) до організму спортсмена $\epsilon$ більш вірогідним, ніж у пересічної людини, тому дуже важливим $\epsilon$ постійний моніторинг маркерів таких важких інфекційних захворювань, як вірусні гепатити та ВІЛ.

За необхідності слід використовувати додаткову лабораторну програму ПМО, основними складовими якої є:

- діагностика ризику кардіологічної дисфрункції і раптової коронарної смерті - гомоцистеїн, ВNP, С-реактивний білок (СРБ), КФК-МВ, тропонін-T, АCT, міоглобін, інтерлейкін-6 (IL-6), ЛДГ (серцева фракція);

- панель остеопорозу - маркер резорбції кісткової тканини (Cross-Laps), маркер формування кісткової тканини (P1NP), дезоксипіридинолін (DPD), ЛФ, остеокальцин, вітамін $D_{3}$, паратиреоїдний гормон (ПТГ). Відомо, що заняття видами спорту аеробної спрямованості, особливо при недостатньо збалансованому і адекватному раціоні харчування у жінок, та прийом заборонених стероїдних та антиестрогенних препаратів у жінок і чоловіків може призводити до розвитку остеопенії та остеопорозу, тому дуже важливо своєчасно виявляти найменші зсуви у кістковому гомеостазі $[4,13,20]$;

- розширена оцінка тиреоїдної функції тиреоглобулін, антитіла до тиреоглобуліну та тиреопероксидази. У зв'язку з несприятливою екологічною ситуацією в Україні, обов'язковим $\epsilon$ скринінг на аутоімунні захворювання щитоподібної залози;

- фуннкціональний стан гіпофрізарно-гонадної системи - вільний тестостерон, андростендіон, лютеотропний гормон (ЛГ), фролікулостимулюючий гормон (ФСГ), адренокортикотропний гормон (АКТГ), кортизол у сечі. При неадекватних фрізичних навантаженнях і незбалансованому раціоні дуже часто розвиваються ендокринні порушення репродуктивної системи $[1,9,12]$, найчастіше у представниць художньої гімнастики та важкої атлетики;

- показники обміну заліза і активності гемопоезу для уточнення генезу спортивної анемії у випадку її виявлення - вітамін $\mathrm{B}_{12}$, фолієва кис- 
лота, трансферин, розчинний рецептор до трансферину, залізозв'язувальна здатність крові;

- про- і антизапальні цитокіни - інтерлейкіни (IL), зокрема IL-1, IL-1 $\beta$, IL-6, I, IL-18, фрактор некрозу пухлини (TNF- $\alpha$ ), IL-4, IL-10, IL-13, розчинні рецептори до TNF. Останнім часом з'являється все більше досліджень, що стосуються визначення цитокінового профрілю для оцінки стану тренованості організму спортсмена та його готовності до змагань [17];

- показники активності метаболічних процесів - комплексний аналіз крові на жиро- і водорозчинні вітаміни (A, D, E, K, C, групи B), рівень гомоцистеїну як маркера вмісту вітамінів групи В та кардіологічної патології; ненасичені жирні кислоти родини омега-3 (ейкозанова - EPA, докозагексаєнова - DHA); органічні кислоти - яблучна, лимонна, щавлева, бурштинова, мурашина тощо; ненасичені жирні кислоти - пальмітинова, стеаринова, олеїнова тощо; амінокислоти; параметри перекисного окиснення ліпідів (ПОЛ) - фрерменти супероксиддисмутаза (СОД) і каталаза, проміжний продукт ПОЛ малоновий діальдегід (МДА) у крові та еритроцитах. При інтенсивних фрізичних навантаженнях за рахунок вираженої гіпоксії підсилюються процеси ПОЛ, і у крові накопичуються продукти цих процесів, які пошкоджують у першу чергу мембранні структури, що $€$ одним із фракторів, лімітуючих фрізичну працездатність [3, 8, 9]. Отже, перераховані показники необхідно визначати для призначення обгрунтованої фармакологічної корекції фрізіологічного стану спортсмена;

- розширений аналіз функції підшлункової залози - панкреатична ліпаза, антитіла до інсуліну, С-пептид, глікозильований гемоглобін або фруктозамін (показники рівня глюкози у крові за останні три місяці чи три тижні відповідно), онкомаркер СА 19-9;

- за показаннями слід провести аналізи на наявність хелікобактерної інфекції, урогенітальних інфекцій (Chlamydia, Ureaplasma, Mycoplasma), TORCH-інфекцій тощо.

II. Етапні комплексні обстеження включають оцінку поточного біохімічного профрілю, що відображає довготривалу адаптацію та резервні можливості організму. Обов'язкова лабораторна програма при ЕКО: загальний аналіз крові, загальний аналіз сечі, гемостаз, оцінка мікроциркуляції, гормональний статус, біохімічний аналіз крові, прооксидантно-антиоксидантний статус та скринінг анемій.

III. Поточне обстеження - це дослідження показників, що дозволяють визначити рівень тер- мінової адаптації організму спортсмена. Програма лабораторного контролю досліджень під час ПО включає:

A. Перелік необхідних лабораторних досліджень під час ПО (З рази протягом учбовотренувального збору або змагання):

- загальний аналіз крові з підрахунком ретикулоцитів та їхніх фрракцій і еритроцитарних характеристик, загальний аналіз сечі;

- біохімічний аналіз крові - кислотно-основний стан, загальний білок, глюкоза, лактат, білірубін, креатинін, сечовина, сечова кислота, альбумін, глобулін, білкові фракції, МСМ, кальцій іонізований, фосфор, калій, натрій, магній, АСТ, АЛТ, $\alpha$-амілаза, ЛФ, ГГТ, ВNP, ЛДГ, КФК, міоглобін;

- гормональний статус (тестостерон, ГЗСГ, інсулін, кортизол);

- прооксидантно-антиоксидантний статус (СОД, МДА, відновлений глутатіон, що $є$ одним із найбільш потужних антиоксидантів неферментативної ланки) [3].

Б. Перелік лабораторних досліджень при тестовому фізичному наßантаженні під час ПО:

- до біохімічного аналізу крові додаються: лактат, ХС, ТГ, фреритин, трансферин, залізо;

- до гормональних досліджень додається визначення вмісту катехоламінів та еритропоетину в крові;

- аналіз сечі доповнюється визначенням вмісту креатиніну та 3-метилгістидину, який $є$ мірою деградації м'язових білків актину і міозину. ПО:

B. Оцінка стомлення і Відновлення під час

- достатні біохімічні маркери: сечовина, вільні жирні кислоти, лактат, загальний білок, альбумін, глобулін, білкові фракції, КФК, ЛДГ, АСТ, міоглобін, магній, калій, кальцій іонізований, хром.

До основного переліку досліджень додається оцінка гемостазу і мікроциркуляції: фрібриноген, ПТІ, АЧТЧ, АТ-ІІІ, розчинні комплекси орібринмономера, Д-димер, фрібриноліз;

Під час формування висновку за лабораторними дослідженнями треба зазначати: оцінку рівня термінової адаптації до тренувальних навантажень і переносимість навантажень; оцінку перенапруження; оцінку пошкодження та травматизації м'язової тканини; дати рекомендації з оперативної корекції (тренувальної і нетренувальної).

При ЕКО слід зазначати: оцінку переносимості навантажень; оцінку довготривалої адаптації; оцінку резервних можливостей; дати рекоменда- 
ції з корекції (тренувальної і позатренувальної, у тому числі фрармакологічної).

При ПМО слід зазначати: оцінку стану здоров'я; дати вказівки на наявність клінічних ознак патології; оцінку функціонального стану спортсмена; дати фармакологічні рекомендації 3 корекції функціонального стану.

Висновки. Таким чином, визначення метаболічних показників згідно з чітко обгрунтованими схемами лабораторного контролю на різних етапах підготовки спортсменів дозволяє вирішувати завдання комплексного обстеження спортсменів, a саме:

- здійснювати контроль за функціональним станом організму, відстежувати адаптаційні зміни в основних енергетичних системах і функціональну перебудову організму у процесі тренування;

- проводити діагностику передпатологічних і патологічних змін метаболізму;

- оцінювати рівень тренованості спортсмена, адекватності застосування позатренувальних (фрармакологічних, фрізіотерапевтичних та ін.) засобів підвищення працездатності й прискорення відновлення [2].

Звичайно, представлені переліки досліджень $\epsilon$ лише орієнтовними і можуть бути розширені чи перетворені залежно від потреб того або іншого виду спорту, команди або окремих спортсменів та окремих тренувальних завдань, поставлених тренером.

\section{Література}

1. Гищак Т.В. Спортивная фрармакология и диетология / Т. В. Гищак, Н. А. Горчакова, Л. М. Гунина [и др.]; под. ред. С. А. Олейника, Л. М. Гуниной. - М.; СПб.: Диалектика, 2008. -249 с.

2. Гуніна Л. М. Уніфікована програма поглибленого медико-біологічного обстеження спортсменів збірних команд України та їх найближчого резерву (проект) / Л. М. Гуніна // Спорт. медицина. - 2009. - № 1-2. - С. 151-154.

3. Гунина Л. М. Биохимический и гематологический контроль и его значение при разработке схем фармакологической поддержки тренировочной и соревновательной деятельности спортсменов / Л. М. Гунина, С. А. Олейник // Наука в олимп. спорте. - 2009. - № 1, Спецвып. C. $177-193$.

4. Гуніна Л. М. Антиестрогенні препарати у клініці та спорті: класифрікація, структура, механізм дії, побічні ефекти. 1. Вибіркові модулятори рецепторів естрогену / Л. М. Гуніна, С. А. Олійник, И. В. Досенко, А. В. Савоста // Спорт. медицина. - 2007. - № 1-2. - С. 84-89.

5. Гунина Л. М. Прогностические изменения показателей белой крови у хоккеистов высокой квалификации на этапе подготовки к соревнованиям / Л. М. Гунина, С. В. Олишевский // Междунар. науч. конф. по вопросам состояния и перспективам развития медицины в спорте высших достижений "СпортМед-2009" (М., 10-11 ноября 2009 г.). - М.: Физкультура и спорт, 2009. C. $47-49$.
6. Гунина Л. М. Сравнительный анализ показателей гематологического гомеостаза венозной и капиллярной крови у спортсменов высокого класса / Л. М. Гунина, С. В. Олишевский, С. С. Коваленко, В. О. Петришина // Наука в олимп. спорте. - 2010. - № 1-2. - С. 59-62.

7. Лабораторные показатели в системе медико-биологического контроля за спортсменами: метод. рекомендации / [сост. Р. Е. Маркина, Е. Н. Конончук]. - К., 2007. - 48 с.

8. Лифошии В. М. Медицинские лабораторные анализы / В. М. Лифршиц, В. И. Сидельников. - М.: Триада-Х, 2007. - 299 c.

9. Макарова Г. А. Лабораторные показатели в практике спортивного врача / Г. А. Макарова, Ю. А. Холявко. М.: Сов. спорт, 2006. - 200 с.

10. Михайлов С. С. Спортивная биохимия / С. С. Михайлов. - М.: Сов. спорт, 2004. - 220 с.

11. Назаренко Г. И. Клиническая оценка результатов лабораторных исследований / Г. И. Назаренко, А. А. Кишкун. - М.: Медицина, 2002. - 544 с.

12. Никулин Б. А. Биохимический контроль в спорте / Б. А. Никулин, И. И. Родионова. - М.: Сов. спорт, 2011. 232 c.

13. Тайболіна Л. О. Діагностика остеопорозу в спортсменів / Л. О. Тайболіна, Л. М. Гуніна // Людина, спорт і здоров'я: материалы II Всеукраїнського з'їзду фрахівців із спортивної медицини та лікувальної фрізкультури (К., 3-5 листоп. 2008 р.). - К., 2008. - С. 72-73.

14. ТкачеВа Д. Л. Долабораторная часть преаналитического этапа гематологических и биохимических исследований крови спортсменов / Д. Л. Ткачева // Актуальные проблемы теории и методики физической культуры, спорта и туризма: материалы IV Междунар. науч.-практ. конфр. молодых ученых (Минск, 21 апреля 2011 г.). - Минск: БГУФК, 2011. - С. 250-252.

15. Шинкарук О. А. Медико-біологічне забезпечення підготовки спортсменів збірних команд України з олімпійських видів спорту: навч.-метод. посіб. / О. А. Шинкарук, О. М. Лисенко, Л. М. Гуніна [та ін.]; за заг. ред. Шинкарук О. А. - К.: Олімп. л-ра, 2009. - 142 с.

16. Ashe Maureen C. Disparity between Physical Capacity and Participation in Seniors with Chronic Disease / Maureen C. Ashe, Janice J. Eng, William C. Miller, Judith A. Soon // Med. Sci. Sports Exerc. - 2007. - Vol. 39, № 7. - P. 1139-1146.

17. Eliakim A. Growth Hormone-Insulin-Like Growth Factor-1 Axis and Cytokine Balance / A. Eliakim, D. Nemet // Cytokines, Growth Mediators and Physical Activity in Children during Puberty / Eds. Jaak Jưrimũe, Andrew P. Hills. - Med. Sport Sci. - 2010. - Vol. 55. - 178 p.

18. Houglum Peggy A. Therapeutic Exercise for Musculoskeletal Injuries. 3rd ed. / Peggy A. Houglum. - US: Human Kinetics, 2010. - $548 \mathrm{p}$.

19. Li L. Mitochondrial biogenesis and peroxisome proliferator-activated receptor- $\gamma$ coactivator-1 $\alpha$ (PGC$1 \alpha$ ) deacetylation by physical activity: intact adipocytokine signaling is required / L. Li, R. Pan, R. Li et al. / / Diabetes. 2011. - Vol. 60, № 1. - P. 157-167.

20. Wilborn C. Effects of a purported aromatase and $5 \alpha$-reductase inhibitor on hormone profiles in college-age men / C. Wilborn, L. Taylor, C. Poole [et al.] / / Int. J. Sport Nutr. Exerc. Metab. - 2010. - Vol. 20, N 6. - P. 457-465.

\section{References}

1. Gischack T.V. Sport pharmacology and diertologe / T. V. Gischack, N. A. Gorchakova, L. M. Gunina [et al.]; Eds. 
S. Oliynick, L. Gunina. - Moscow-Saint-Peterburg: Dialecktika, 2008. - 249 p. (in Russian).

2. Gunina L. M. Compatible program of deep medical and biological inspection of sportsmen of collapsible commands of Ukraine and them the nearest reserve(project) / L. M. Gunina // Medicine of sport. - 2009. - N 1-2. - P. 151-154.

3. Gunina L. M. Biochemical and haematological control and his value at development of charts of pharmacological support of training and competition activity of sportsmen / L. M. Gunina, S. A. Oliynick // Science in Olympic Sport. 2009. - N 1, Iss. - P. 177-193.

4. Gunina L. M. Antiestrogen preparations in a clinic and sport: classification, structure, mechanism of action, side effects. 1. Selective keyers of receptors of estrogen / L. M. Gunina, S. A. Oliynick, I. V. Dosenko, A. V. Sawosta // Medicine of sport. - 2007. - N 1-2. - P. 84-89.

5. Gunina L. M. Prognostic changes of indexes of white blood for the hockey players of high qualification on the stage of preparation to the competitions / L. M. Gunina, S. V. Olishevsky // Int. scientific Conf. on questions of the state and prospects of development of medicine in sport of higher achievements "SportMed-2009" (Moscow, 2009 on November, 10-11). - Moscow: Phizkultura and sport, 2009. - P. 47-49.

6. Gunina L. M. Comparative analysis of indexes of haematological homoeostasis of venous and capillary blood for the sportsmen of high class / L. M. Gunina, S. V. Olishevsky, S. S. Kovalenko, V. O. Petrishina // Science in Olympic Sport. - 2010. - N 1-2. - P. 59-62.

7. Laboratory indexes in the medico-biological checking system after sportsmen: Methodical recommendations / compilers R. E. Markina, E. N. Kononchuck. - Kiev, 2007. $48 \mathrm{p}$.

8. Liphschits V. M. Medical labtests / V. M. Liphschits, V. I. Sidel'nikov. - Moscow: Triade-X, 2007. - 299 p.

9. Makarova G. A. Laboratory indexes are in practice of sporting doctor / G. A. Makarova, Ju. A. Choljavko. Moscow: Soviet Sport, 2006. -200 p.

10. Mickhailov S. S. Biochemistry of sport / S. S. Mickhailov. - Moscow: Soviet Sport, 2004. - 220 p.

11. Nazarenko G. I. Clinical estimation of results of laboratory researches / G. I. Nazarenko, A. A. Kishkun. Moscow: Medicine, 2002. - 544 p.
12. Nikulin B. A. Biochemical control is in sport / B. A. Nikulin, I. I. Rodionova. - Moscow: Soviet Sport, 2011. - $232 \mathrm{p}$.

13. Taybolina L. O. A osteoporosis diagnostics in sportsmen / L. O. Taybolina, L. M. Gunina / / Man, sport and health: Materials II of Ukrainian convention of specialists on sporting medicine and curative physical education (Kiev, 2008 on November, 3-5). - Kiev, 2008. - P. 72-73.

14. Tckacheva D. L. Prelaboratory part of the preanalytical stage of haematological and biochemical analyses of blood of sportsmen / D. L. Tckacheva // Issues of the day of theory and methodology of physical culture, sport and tourism: Materials IV of the Int. research and practice conference of young scientists (Minsk, 2011on April, 21). Minsk: SUPCB, 2011. - P. 250-252.

15. Shinkaruck O. A. Medical and biolocical providing of preparation of sportsmen of collapsible commands of Ukraine from the olympic types of sport: educational and methodical manual / O. A. Shinkaruck, O. M. Lisenko, L. M. Gunina [et al.]; Ed. Shinkaruck O. A. - Kiev: Olymp. lit., 2009. - 142 p.

16. Ashe Maureen C. Disparity between Physical Capacity and Participation in Seniors with Chronic Disease / Maureen C. Ashe, Janice J. Eng, William C. Miller, Judith A. Soon // Med. Sci. Sports Exerc. - 2007. - Vol. 39, N 7. - P. $1139-1146$.

17. Eliakim A. Growth Hormone-Insulin-Like Growth Factor-1 Axis and Cytokine Balance / A. Eliakim, D. Nemet // Cytokines, Growth Mediators and Physical Activity in Children during Puberty / Eds. Jaak Jưrimữe, Andrew P. Hills. - Med. Sport Sci. - 2010. - Vol. 55. - 178 p.

18. Houglum Peggy A. Therapeutic Exercise for Musculoskeletal Injuries. 3rd ed. / Peggy A. Houglum. - US: Human Kinetics, 2010. - 548 p.

19. Li L. Mitochondrial biogenesis and peroxisome proliferator-activated receptor- $\gamma$ coactivator- $1 \alpha$ (PGC- $1 \alpha)$ deacetylation by physical activity: intact adipocytokine signaling is required / $\mathrm{L}$. Li , R. Pan, R. Li et al. // Diabetes. 2011. - Vol. 60, N 1. - P. 157-167.

20. Wilborn C. Effects of a purported aromatase and $5 \alpha$-reductase inhibitor on hormone profiles in college-age men // C. Wilborn, L. Taylor, C. Poole [et al.] // Int. J. Sport Nutr. Exerc. Metab. - 2010. - Vol. 20, N 6. P. $457-465$. 